\title{
Could Grasshoppers Be a Nutritive Meal?
}

\author{
Julieta Ramos-Elorduy Blásquez*, José Manuel Pino Moreno, Víctor Hugo Martínez Camacho \\ Instituto de Biología, Departamento de Zoología, Universidad Nacional Autónoma de México, Ciudad de México, México. \\ Email: *relorduy@ibunam2.ibiologia.unam.mx
}

Received June 21 $1^{\text {st }}$, 2011; September $27^{\text {th }}$, 2011; accepted October $3^{\text {rd }}, 2011$

\begin{abstract}
The nutritive value of 25 edible Orthoptera in Mexico is shown. Protein content ranges from 43.93\% to 77.13\% (mix of Edible Acrididade of Puebla). Fat percentage goes from 4.22\% to 34.21\%. Richest species in ashes were Arphia fallax S., Sphenarium histrio G. and Sphenarium purpurascens Ch. with 16.5\%. Energy contribution varies from $14.05 \mathrm{~kJ}$ to $21.88 \mathrm{~kJ}$. Their amino acids profile was compared with the WHO/FAO/UNU Pattern (1985). The total quantity of essential amino acids that all insects species provides was superior to those signaled in the pattern. The highest quantity (53.60 g) was for Sphenarium histrio G. Chemical score goes from 50\% to 88\%. In vitamins, the highest value in Thiamine and Riboflavine was for Sphenarium magnum M., in Niacine for Sphenarium borrei B., in vitamin C and for vitamin D Acheta domestica L., and in Vitamin A for Periplaneta americana L. In minerals, all species were very rich in magnesium. All the edible orthopterans results were compared with those of the most conventional mexican foods used to obtain proteins. The quantity and quality of the nutrients that these edible orthopterans allows, provides a significant contribution to the nutrition of the peasants who eat them.
\end{abstract}

Keywords: Edible; Orthoptera; Nutritive; Value; Mexico; Proteins; Fats; Energy

\section{Introduction}

Among the alternative food that exists, are the grasshoppers. They have a lot of qualities, being primary consumers from ecological point of view, another very important is that even if they are univoltines, constituted a so enormous biomass that people all over the world prepare and eat them [1-4], forward sell or store them, once they are dried.

For this they use different tools and nets of different size, catching by one or various individuals together of variable species and ages. They do that with diverse goals, the main is to use as food, or to give them as gift or as merchandise to sell and/or store, for have something to eat in bad times.

In Mexico the consumption of diverse species of insects by the human beings (Anthropoentomophagy) [5] is an alimentary tradition that still persists [6], such as those of the well-known edible insects, like the white (Aegiale hesperiaris) and red (Comadia redtenbacheri) agave worms, the "ahuahutle" (eggs of Corixidae and Notonectidae bugs) and "axayacatl" (adults of ahuahutle), of the "jumiles” (Edessa sp.), etc., ingested since prehispanic times $[7,8]$. Most species are ingested in their immature stages (eggs, larvae or pupae) only in a few insects are consumed as adults [9]. In the case of orthopterans all stages

\footnotetext{
"Corresponding author.
}

are eaten. Frequently, a mix of species is eaten as it happens in the case of many grasshoppers species or the water bugs of the families Corixidae and Notonectidae ("ahuahutle" and "axayacatl”) and several wood worms species, because two or three species often coexists together or are sympatric.

For peasants, edible insects are considered as "food to grill" generally prepared on an earthen grill or directly on charcoal. Rural qualified them as clean, savory and tasty little animals [10].

Some edible insects species are marketed in different rural areas, others are selling at a very high price once they are prepared and can as it happens with rice grasshoppers (Oxya velox (Fabricius)) in Japan, Thailand, China, Cambodia, Vietnam, etc. or with different grasshopper (Zonocerus elegans (Thunberg)), Dictyophorus spumans (Thunberg), Phymateus leprosus (Fabricius), P. morbillosus (Linneo)) in South Africa [9,11,12] and thus, they represent a source of food and money to people of local communities [9,13].

Insects are used as food in many parts of the world; for example in all Central America and Brazil, Equator, Peru, Venezuela, Colombia, also in Canada, United States of America. Moreover in all Asia, Africa or Australia [1-5].

In relation with their nutritive value, several authors have shown that edible insects contains large quantities of proteins of high biological value, [10,14-27], of good 
quality [13,20,28-33] and with a high level of digestibility "in vitro" and "in vivo" [16,34-37] For these reasons insects have been postulated as a source of proteins $[15,22,28,38$,$] . Edible insects also have a great energetic$ value $[17,18,39,40]$.

Nowadays, we have recorded 547 species of edible insects in México [41], among them: mayflies, dragonflies, grasshoppers, crickets, cockroaches, termites, bugs, cicadas, treehoppers, leafhoppers, Dobsonflies, beetles, caddisflies, butterflies, flies, mosquitoes, bees, bumblebees, wasps and ants.

In the case of the order Orthoptera in Mexico, we have recorded 85 edible species, 54 species belonging to family Acrididae, twelve species of Tettigonidae, 12 species of Blattidae, five species of Gryllidae, three species of Stenopelmatidae and one species of Phasmidae.

We selected several of the most searched and ingested orthopterans (25) species, with wider distributions in the country, to determine their nutritive value and evaluate their contribution to the diet of peasants in different States and ethnos of Mexico and also compare the obtained values with those provided most popular by the Mexican conventional foods, richest in nutrients.

\section{Materials and Methods}

\subsection{Sampling}

Insects previously determined as edible, were collected in several States of Mexico. Samples were gathered using entomological nets, tweezers and by hand. Collected material was kept at $-40^{\circ} \mathrm{C}$, in flasks with labels identifying place, date and collector, hosts and the common or local (dialect) name.

\subsection{Identification}

The mounting, labeling, and taxonomic identification of collected species was made according to appropriated keys according to Otte [42,43] and verified by the specialists in this order at the Laboratory of Entomology of Institute of Biology of the National Autonomous University of Mexico (IBUNAM).

All the insects have been deposited in the National Collection of Edible Insects at the IBUNAM.

\subsection{Apparati}

To determine water and dry matter, a Thelco model 28 oven was used. Proteins were determined with a Construction Company No. 2730 Kjeldahl Laboratory. Fats were extracted with a Soxhlet flask and a Whatmann cartridge; and fat content was determined with a Precision Scientific Company Soxhlet. To determine ash content, we used a Thermolyne type 1500 oven. Crude fiber was determined with a Construction Company 907 Digestor La- boratory and a Thermolyne type 2200 hot plate. Carbohydrates were determinate by difference.

For amino acid determination [33] a Gold Liquid Chromatography HPLC system from Beckmann (San Ramon, CA U.S.A) combined with: (A) a Model 126 programmable solvent module with an Altex 210A injection valve, (B) a Nec PC 8300 Controller System, (C) a model 427 integrator and (D) a model 121 fluorometer from Gilson (excitation filter $360 \mathrm{~nm}$ and emission filter $450 \mathrm{~nm}$ ); an Ultrasphere XL ODS column (3 mm) and guard column (237520) both from Beckmann, were used.

A speed Vac Concentrator from Savant, a Multi-Flame burner from Fisher, a Multi-Block heater (No. 2093) from Lab-Line Instruments, Inc. (Melrose Park, IL U.S.A) and a PHM 84 research pH meter from Radiometer-Copenhagen were also used in the hydrolysis of the samples at the time of preparation. Samples and solvents were filtered through $0.22 \mathrm{~mm}$ porous membranes (XX3001200 and GVWP04-700) from Millipore (Milford, MA USA).

The caloric content was measured in an oxygen bomb calorimeter from Parr Instruments Co. Int. [44]. The results were reported in kilocalories.

\subsection{Reagents}

The following reagents were used in the proximate analysis: sulfuric acid, boric acid, sodium hydroxide, selenium, ether from Baker (J. T. Baker, S. A. de C. V., Xalostoc Mexico); clorhydric acid and hexane from Merck laboratories (Calle 5 No. 7 Fraccionamiento Industrial Alce Blanco, 53,370, Naucalpan de Juárez Estado de México); Phenolphtalein and green bromocresol were from Sigma of Mexico, (Durango 104, Mexico 7 D.F.).

HPLC grade water was prepared by filtering the deionized water through an organic cartridge from Millipore. Methanol (HPLC grade) was obtained from Baker, sodium acetate from Sigma, and O-phthaldehyde (OPA) from Beckmann. The ingredients used were: water $91.5 \%$, potassium hydroxide $2 \%$, potassium borate $5 \%$, methanol 1\%, mercaptoethanol 0.3\%, OPA 0.1\%, and Brij 35 0.1\%. The amino acid kit 22 was purchased from Pierce. Certified fish protein CPSP-90 labeled by Cooperative de Traitment des Produits de la Pêche” was used as the standard.

Essential amino acids were determinate with a LKB 4400-001 Amino Acid Analyzer using iodoacetic acid, obtained from Sigma, hydrochloric acid (6 N) from Pierce, and methanesulphonic acid (4 N) from Pierce (Rockford, Illinois 61105 USA).

\subsection{Chemical Analysis}

All samples were preserved in liquid nitrogen at $-40^{\circ} \mathrm{C}$ and then dried in an oven at $50^{\circ} \mathrm{C}$ for 3 days. The chemical analyses were performed at the Animal Nutrition and Biochemistry Department of the Faculty of Veterinary Me- 
dicine and Animal Breeding at the National University Autonomous of Mexico (UNAM) using the techniques of the Association of Official Analytical Chemist [45]. Derminations; were performed for water content (AOAC No. 934.09), fat (AOAC No. 920.39), crude fiber (strucral carbohydrates) (AOAC No. 962.09), mineral salts (AOAC No. 924.05) and nitrogen-free extract (AOAC No. 968.07). Crude proteins were also determined using the Kjeldahl method (AOAC No. 984.05), and the N conversion factor was 6.25.

Water percentage was calculated by drying the sample in an oven Felisa at $50^{\circ} \mathrm{C}$ during $48 \mathrm{~h}$. Fat percentage was calculated by drying fats by extraction in a Soxhlet using petroleum ether; mineral salts by calcinations in a furnace; and crude fiber through two digestions, one with sulfuric acid $(1.24 \mathrm{~N})$ the other with sodium hydroxide $(1.25 \mathrm{~N})$.

Amino acid content was determined at the Amino Acid Analysis Unit of the Biomedical Research Institute of the UNAM, a laboratory certified by the Ministry of Public Health under Authorization No. 29544, using high performance liquid chromatography HPLC (Ladrón de Guevara et al., 1995). The external standard procedure was used to quantify the amino acids. This method was calibrated with certified fish protein. The $95 \%$ confidence limits (C. L.) $(t=2.78$ based on 5 replicates $)$ were determined in $\mathrm{g} / 100 \mathrm{~g}$ of each amino acid.

\section{Vitamins}

Vitamin determinations were made by the laboratory American Quality S. A. Vitamin A and D were determined by HPLC in normal phase. Other vitamins were analyzed using the procedures of the AOAC (1975), vitamins C (No. 967.21), Thiamine (No. 942.23), Riboflavine (No. 970.65) and Niacine (No. 961.14).

\subsection{Minerals}

Mineral elements were quantified by atomic absorption using a Pye Unicam spectrophotometer Model SP-192 of Perkin Elmer.

We analyzed some conventional foods in the same way, to can compare their nutritional value.

Results are the mean of three determinations, and the standard deviation is reported.

\section{Results and Discussion}

The edible Orthoptera species studied are shown in Table 1, there are including the species recorded as edible

Table 1. Taxonomy of some edible Orthoptera of Mexico.

\begin{tabular}{|c|c|c|c|c|c|}
\hline Family & Genus & Species & Provinces of consumption & Common name & Consumption stages \\
\hline \multirow[t]{16}{*}{ Acrididae (Grasshoppers) } & Melanoplus & mexicanus S. & Hidalgo. Oaxaca. & Chapulín migratorio & Larvae and Adults \\
\hline & Melanoplus & femurrubrum D.G. & Veracruz. & Chapulín de patas rojas & Larvae and Adults \\
\hline & Encoptolophus & herbaceus B. & Hidalgo. & Chapulín de la hierba & Larvae and Adults \\
\hline & Arphia & fallax $\mathrm{S}$. & Hidalgo. & Chapulín, Acachapoli & Larvae and Adults \\
\hline & Boopedon & flaviventris S. & Hidalgo, Oaxaca. & Chapulín cola clara & Larvae and Adults \\
\hline & Sphenarium & histrio G. & Oaxaca. & Chapulín del zacate & Larvae and Adults \\
\hline & Sphenarium & borrei $B$. & Mexico. & Chapoli & Larvae and Adults \\
\hline & Sphenarium & purpurascens Ch. & Oaxaca, Puebla. & Chapulín de la milpa & Larvae and Adults \\
\hline & Sphenarium & magnum $\mathrm{M}$. & Oaxaca. & Chapulín bandera & Adults \\
\hline & Sphenarium & mexicanum S. & Puebla. & Chapulín del maíz & Adults \\
\hline & Romalea & sp. & Chiapas. & Grillo oscuro & Larvae and Adults \\
\hline & Taeniopoda & auricornis W. & Veracruz. & Grillo negro & Larvae and Adults \\
\hline & Taeniopoda & sp. & Veracruz. & Grillo prieto & Larvae and Adults \\
\hline & Plectrottetia & nobilis W. & Veracruz. & - & Larvae and Adults \\
\hline & Trimerotropis & sp. & Distrito Federal. & Chapulin-cito & Adults \\
\hline & Osmilia (Abracris) & flavolineata D.G. & Chiapas. & Grillo blanco & Larvae and Adults \\
\hline \multirow[t]{2}{*}{ Tettigonidae (Katydids) } & Idiarthron & subquadratum S. \& P. & Chiapas. & Chacuatete & Larvae and Adults \\
\hline & Conocephalus & triops L. & Chiapas. & Esperanza & Adults \\
\hline \multirow[t]{2}{*}{ Gryllidae (Crickets) } & Acheta & domestica L. & Michoacán. & Grillitos & Larvae \\
\hline & Brachytrupes & sp. & Sinaloa & Grillo Gordo & Adults \\
\hline \multirow[t]{3}{*}{ Blattidae (Cockroaches) } & Blaberus & sp. & Guerrero. & Cucaracha grande & Adults \\
\hline & Periplaneta & americana L. & Guerrero. & Cucaracha oscura & Larvae and Adults \\
\hline & Periplaneta & australasiae F. & Veracruz. & Cucarachita & Larvae and Adults \\
\hline
\end{tabular}


in Mexico, family, cientific name, place of collection, consumption stage and common name. The samples belong to the families Acrididae, Tettigonidae, Gryllidae and Blattidae.

The chemical primary parameters of some species stu- died, are shown in Table 2. Sometimes, peasants ingested various species together, and they were analyzed and reported as a mixture. We also indicate the developmenttal stages analyzed in each species. Results are expressed in dry weight basis.

Table 2. Chemical proximate analysis and energy of some edible Orthoptera from Mexico (g/100g of dried sample).

\begin{tabular}{|c|c|c|c|c|c|c|}
\hline Studied species and Consumed Stage & Proteins & Fats & Ashes & Crude fiber & Carbohydrates & $\mathrm{kJ}$ \\
\hline \multicolumn{7}{|l|}{ Hidalgo State } \\
\hline Melanoplus mexicanus S. (L.A.) & $58.9 \pm 3.4$ & $11.0 \pm 1.2$ & $3.94 \pm 0.5$ & $10.01 \pm 3.0$ & $16.5 \pm 2.5$ & 16.31 \\
\hline Encoptolophus herbaceus B. (L.A.) & $57.6 \pm 1.6$ & $11.8 \pm 2.0$ & $2.87 \pm 1.0$ & $11.02 \pm 2.8$ & $17.22 \pm 2.7$ & 16.94 \\
\hline Arphia fallax S. (L.A.) & $71.3 \pm 1.4$ & $6.52 \pm 1.7$ & $2.41 \pm 0.0$ & $11.58 \pm 2.6$ & $8.11 \pm 1.3$ & 16.27 \\
\hline Boopedon flaviventris B. (L.A.) & $59.3 \pm 0.0$ & $11.0 \pm 2.4$ & $2.98 \pm 1.1$ & $10.10 \pm 1.8$ & $16.59 \pm 2.6$ & 16.81 \\
\hline Sphenarium borrei B. (L.A.) & $63.7 \pm 1.3$ & $10.4 \pm 1.9$ & $3.96 \pm 0.8$ & $9.81 \pm 1.4$ & $12.4 \pm 2.0$ & 16.61 \\
\hline \multicolumn{7}{|l|}{ Oaxaca State } \\
\hline $\begin{array}{l}\text { Melanoplus mexicanus S. (L.A.) Boopedon } \\
\text { flaviventris B. (L.A.) Sphenarium spp. (L.A.) \&," }\end{array}$ & $77.1 \pm 2.8$ & $4.22 \pm 0.5$ & $2.44 \pm 0.5$ & $12.17 \pm 2.8$ & $4.01 \pm 0.5$ & 15.14 \\
\hline $\begin{array}{l}\text { Arphia fallax S. (A.), Sphenarium histrio G. (A.), } \\
\text { Sphenarium purpurascens Ch. (L.A.) \& }{ }^{*}\end{array}$ & $58.3 \pm 1.5$ & $7.41 \pm 2.0$ & $16.5 \pm 1.0$ & $8.64 \pm 1.2$ & $9.11 \pm 1.4$ & 12.80 \\
\hline Sphenarium magnum M. (A.) & $66.5 \pm 1.4$ & $7.37 \pm 1.5$ & $1.68 \pm 0.9$ & $11.3 \pm 2.6$ & $13.10 \pm 2.2$ & 16.06 \\
\hline \multicolumn{7}{|l|}{ Puebla State } \\
\hline Sphenarium spp. (L.A.) & $67.8 \pm 2.1$ & $11.5 \pm 2.0$ & $4.87 \pm 0.3$ & $10.51 \pm 1.1$ & $4.65 \pm 0.6$ & 16.44 \\
\hline Sphenarium purpurascens Ch. (A.) & $65.2 \pm 1.2$ & $10.8 \pm 0.7$ & $2.95 \pm 0.7$ & $9.41 \pm 1.3$ & $11.63 \pm 1.9$ & 16.90 \\
\hline Sphenarium mexicanum S. (A.) & $62.1 \pm 1.5$ & $10.8 \pm 1.7$ & $0.34 \pm 0.1$ & $4.06 \pm 0.5$ & $22.64 \pm 2.9$ & 18.24 \\
\hline \multicolumn{7}{|l|}{ Chiapas State } \\
\hline Romalea sp. (L.A.) & $75.3 \pm 0.8$ & $12.3 \pm 2.0$ & $4.25 \pm 0.4$ & $9.73 \pm 1.3$ & $0.19 \pm 0.1$ & 17.23 \\
\hline Romalea colorata S. (L.A.) & $72.7 \pm 1.4$ & $16.3 \pm 0.7$ & $4.64 \pm 0.6$ & $6.33 \pm 1.5$ & $0.001 \pm 0.1$ & 18.28 \\
\hline Idiarthron subquadratum S \& P.(L.A.) & $65.2 \pm 1.1$ & $8.17 \pm 1.1$ & $3.79 \pm 1.0$ & $11.10 \pm 2.5$ & $4.42 \pm 0.5$ & 14.68 \\
\hline \multicolumn{7}{|l|}{ Veracruz State } \\
\hline Conocephalus triops L. (A) & $71.0 \pm 0.6$ & n.d. & n.d. & n.d & n.d. & n.d. \\
\hline Taeniopoda auricornis W. (L.A.) & $63.0 \pm 1.8$ & $10.2 \pm 0.9$ & $3.97 \pm 0.8$ & $8.34 \pm 1.1$ & $14.52 \pm 2.3$ & 16.77 \\
\hline Taeniopoda sp. (L.A.) & $71.0 \pm 2.0$ & $5.85 \pm 1.0$ & $2.95 \pm 0.9$ & $10.56 \pm 1.9$ & $9.59 \pm 1.6$ & 15.48 \\
\hline $\begin{array}{l}\text { Taeniopoda sp. (L.A.), P. nobilis W. (L.A.), } \\
\text { M. Fémur-rubrum D.G. (L.A.) \& }\end{array}$ & $70.9 \pm 1.7$ & $6.06 \pm 1.7$ & $3.95 \pm 0.3$ & $9.56 \pm 1.3$ & $9.51 \pm 1.6$ & 15.73 \\
\hline \multicolumn{7}{|l|}{ Distrito Federal } \\
\hline Trimerotropis sp. (L.A.) & $65.1 \pm 2.0$ & $7.02 \pm 0.6$ & $3.78 \pm 0.0$ & $10.2 \pm 3.0$ & $10.20 \pm 1.7$ & 15.25 \\
\hline \multicolumn{7}{|l|}{ Michoacán State } \\
\hline Acheta domestica L. (L.) & $64.1 \pm 1.2$ & $24.0 \pm 0.9$ & $3.55 \pm 0.9$ & $6.2 \pm 1.5$ & $2.12 \pm 0.3$ & 20.11 \\
\hline \multicolumn{7}{|l|}{ Sinaloa State } \\
\hline Brachytrupes sp. (A) & $61.2 \pm 1.1$ & $18.7 \pm 0.9$ & $5.05 \pm 0.5$ & $7.42 \pm 1.0$ & $7.60 \pm 0.7$ & 18.54 \\
\hline \multicolumn{7}{|l|}{ Guerrero State } \\
\hline Blaberus sp. (A.) & $43.9 \pm 1.5$ & $34.2 \pm 1.9$ & $3.33 \pm 0.6$ & $8.44 \pm 1.1$ & $10.09 \pm 1.8$ & 21.88 \\
\hline Periplaneta americana L. (L.A.) & $65.6 \pm 1.9$ & $28.2 \pm 2.0$ & $2.48 \pm 0.3$ & $3.00 \pm 0.9$ & $0.78 \pm 0.0$ & 21.70 \\
\hline Periplaneta australasiae F. (L.A.) & $62.4 \pm 1.6$ & $27.3 \pm 1,5$ & $3.00 \pm 0.2$ & $4.50 \pm 0.7$ & $2.73 \pm 0.2$ & 21.17 \\
\hline
\end{tabular}

Source: ${ }^{[}$27] values a1ready reported for Oaxaca state. \& Mixed species eaten together and analyzed in this way. n.d. = no determined L. = Larvae, A. = Adults. 
The protein content ranged from $43.9 \%$ to $77.1 \%$. The highest quantity was found in the mix of species Melanoplus mexicanus (Saussure), Boopedon flaviventris Bruner and Sphenarium spp., and the lowest in Blaberus sp. The opposite happens in the fat content, with the percentages going from a high of $34.2 \%$ in Blaberus sp. to the lowest $4.22 \%$ in the mixture of Melanoplus mexicanus (Sauss.), Boopedon flaviventris B. and Sphenarium spp. In ashes, the richest insects were the mixture of Arphia fallax Saussure, Sphenarium histrio Gerstaecker, and Sph. Purpurascens Charpentier already bought at Puebla market.

We calculate that $3.44 \%$ (one grasshoppers species) has between $40 \%$ of protein, $20.08 \%$ (six species) among $50 \%$ and $60 \%$, $48.27 \%$ (14 species) among $60 \%$ and $70 \%$, and $27.58 \%$ (eight species) among 70\% and $80 \%$.

Values reported of protein percentage in these insects were superior to some mexican conventional foods used as source of protein (beans, lentils), and similar to those of soybean, chicken, eggs and beef; only fish have a higher protein content (Table 3).

Energy contribution of edible mexican Orthoptera varies from 14.05 Kilojoules (Arphia fallax S., Sphenarium histrio G., Sph. purpurascens Ch.) to 21.88 Kilojoules in Blaberus sp. (Table 4).

Table 3. Range of protein content of edible Orthoptera of Mexico compared with some mexican conventional foods (g/100g of dried sample).

\begin{tabular}{cc}
\hline Order & Percentage \\
\hline Orthoptera & $43.9 \pm 1.5-77.1 \pm 2.8$ \\
Conventional foods & Percentage \\
Beans & $23.5 \pm 1.0$ \\
Lentils & $26.7 \pm 0.8$ \\
Soybean & $41.1 \pm 0.5$ \\
Chicken & $43.3 \pm 0.6$ \\
Egg & $46.0 \pm 1.1$ \\
Beef & $54.0 \pm 0.7$ \\
Fish & $81.1 \pm 0.8$
\end{tabular}

Table 4. Energy supplied by some edible Orthoptera of Mexico compared with conventional foods (cal/1000g) ${ }^{*}$.

\begin{tabular}{|c|c|c|}
\hline Orthopterans & $\mathrm{kJ}$ & Conventional foods \\
\hline & 12.24 & Bean \\
\hline \multirow[t]{2}{*}{7 Arphia fallax S., Sphenarium histrio G. Sph. purpurascens Ch. } & 14.05 & \\
\hline & 14.22 & Lentil \\
\hline 14 Idiarthron subquadratum S. \& P. & 14.68 & \\
\hline 6 Melanoplus mexicanus S., Boopedon flaviventris S., Sphenarium spp. & 15.14 & \\
\hline & 15.32 & Carrot \\
\hline 17 Taeniopoda sp. & 15.48 & \\
\hline 18 Taeniopoda sp. (L.A.), P. nobilis W. M. fémur-rubrum D.G. & 15.73 & \\
\hline 8 Sphenarium magnun $\mathrm{M}$. & 16.08 & \\
\hline 3 Arphia fallax S. & 16.27 & \\
\hline 1 Melanoplus mexicanus S. & 16.31 & \\
\hline & 19.60 & Soybean \\
\hline 5 Sphenarium borrei B. & 16.61 & \\
\hline 6 M. mexicanus S., B. flaviventris S., Sphenarium spp. & 16.77 & \\
\hline 4 Boopedon flaviventris $S$. & 16.81 & \\
\hline 10 Sphenarium purpurascens Ch. & 16.90 & \\
\hline 2 Encoptolophus herbaceus B. & 16.94 & \\
\hline \multirow[t]{2}{*}{12 Romalea sp. } & 17.23 & \\
\hline & 17.80 & Amaranth \\
\hline 11 Sphenarium mexicanum $S$. & 18.24 & \\
\hline \multirow[t]{2}{*}{13 Romalea colorata S. } & 18.28 & \\
\hline & 18.37 & Beef \\
\hline 21 Brachytrupes sp. & 18.54 & \\
\hline 24 Periplaneta australasiae F. & 21.17 & \\
\hline 23 Periplaneta americana L. & 21.70 & \\
\hline 22 Blaberus sp. & 21.88 & \\
\hline
\end{tabular}

* Modified from [46]. 
In Table 5 we compared the total energy supplied by some edible orthopterans with conventional foods, in average the insects are higher that conventional vegetables: verdures, broad, beans, lentils, pea, chick pea, in the cereals: rye, wheat, rice, oats, maize, and the animals: chicken, fish and beef with the exception of the soybean and pork. The amino acid profile of nine studied species is compared with the preschooler and adult requirements indicated by the WHO/FAO/UNU pattern [47]. In the case of values for all essential amino acids given for adults signaled in it for all essential amino acids, each one of insects species provides higher quantities than those of the pattern and with the values given for preschoolers, we can note that Melanoplus femurrubrum (De Geer) is slightly deficient in isoleucine.

In leucine, are slightly Melanoplus femurrubrum (De Geer), Periplaneta australasiae Fabricius, Periplaneta americana Linneo and deficient Taeniopoda auricornis (Walker).

In lysine all species have shown a very low degree of deficiency, with the exception of Melanoplus femurrubrum (De Geer) and Brachytrupes sp. The rest of species are generally slightly deficient, some of them showing minimal differences with the standard values, but Periplaneta americana Linneo and Taeniopoda auricornis (Walker) are deficient.

In threonine are very slightly deficient Sphenarium purpurascens Ch. and Periplaneta australasiae Fabricius and deficient Taeniopoda auricornis (Walker), also in histidine the last one.

In sulfur amino acids Brachytrupes sp. have very low degree of deficiency and aromatic amino acids, and in valine, all the species provide enough quantity of them to meet the standard but all species are limitants in tryptophan, nevertheless, all edible insects posses more quantity of total essential amino acids than both patterns (Table 6).

The highest percentage of total essential amino acids (53.60) was for Sphenarium histrio Gerstaecker and the lowest (35.45) was for Periplaneta australasiae Fabricius. Most of species have an adequate nutritional profile of essential amino acids, even though some of them do not reach the highly demanding quantities for preschooler [48] requirements. The insect's protein quality score done by their content in tryptophan ranged from $50 \%$ (Brachytrupes sp.) to $88.18 \%$ in Melanoplus femurrubrum (De Geer) (Table 6).

The Orthopteran species with the lower values in total content of essential amino acids, even have a bigger proportion of them than beans, lentils, and soybean; and those species with the highest values exceed all vegetal and animals products analyzed (Table 7).

In vitamins the highest values are: in thiamine and riboflavine Sphenarium magnum M. adults; in niacine Sp- henarium borrei Bruner adults. In vitamin C and D Acheta domestica Linneo larvae and in vitamin A Periplaneta americana Linneo larvae, (Table 8). In Table 9 we compare the quantities of vitamins that these insects possess with conventional foods: Orthopteran studied in its highest value presented more thiamine than all other analyzed products with the exception of yeast. Orthopteran species contains more riboflavine than all other analyzed products except liver. When we analyze niacine content, insects have more than milk and eggs. In Vitamin $C$ they have more than only the watermelon. In Vitamin A edible Orthoptera have less than eggs, milk, gourd, spinach, carrot and liver. All the values of the conventional products were taken from [47].

In relation with the total ashes and sodium the mixture of Sphenarium histrio G., Sphenarium purpurascens Ch. and Melanoplus femurrubrum D.G., bought at a Puebla market already cooked and fixed, had the highest values. In potassium, were Sphenarium magnum M. and Sphenarium purpurascens $\mathrm{G}$. that presented the highest content. With regards to calcium, Sphenarium spp. and $M e-$ lanoplus mexicanus S. were the richest. In Zinc was Sphenarium histrio G. and the mix of Sphenarium spp., Arphia fallax Saussure, Boopedon af. flaviventris B., M. mexicanus S. and E. herbaceous. In iron, Sphenarium purpurascens $\mathrm{Ch}$. and the mixture of Boopedon af. Flaviventris B, Sphenarium borrei B., and Melanoplus mexicanus S. In magnesium, Boopedon af. flaviventris B., Melanoplus mexicanus S. and Sphenarium borrei B. were the highest (Table 10). Comparing the mineral proportion supplied by the edible Orthoptera of Mexico, with respect to the values of conventional foods, we can see that insects have more sodium than all foods analyzed, with the exception of wheat in their low value. Potassium content in edible Orthoptera was superior to all of them

Table 5. Energy supplied by some edible Orthoptera of Mexico compared with conventional foods (cal./1000g)

\begin{tabular}{lllr}
\hline \multicolumn{2}{c}{ Order } & \multicolumn{2}{c}{$k J$} \\
\hline \multicolumn{2}{c}{ Orthoptera } & \multicolumn{2}{c}{$3319.3-5239.7$} \\
Vegetables & \multicolumn{2}{c}{ Cereals } \\
Verdures & 1506.2 & Rye & 1397.5 \\
Broad bean & 1624.2 & Wheat & 1397.5 \\
Beans & 1637.4 & Rice & 1510.4 \\
Lentils & 1644.4 & Oats & 1523.0 \\
Pea & 1673.2 & Maize & 1548.1 \\
Chick-pea & 1763.9 & Animals \\
Soybean & 1944.7 & Chicken & 688.7 \\
& & Fish & 1662.3 \\
& & Beef & 1735.9 \\
& & Pork & 2948.5 \\
\hline
\end{tabular}

${ }^{*}$ Modified from [46]. 
Table 6. Amino acid content of some edible Orthoptera from Mexico (g/100g of protein).

\begin{tabular}{|c|c|c|c|c|c|c|c|c|c|c|c|}
\hline $\begin{array}{l}\text { Species, } \\
\text { Analized }\end{array}$ & $\begin{array}{l}\text { Sphenarium } \\
\text { histrio G.+ }\end{array}$ & $\begin{array}{c}\text { Sphenarium } \\
\text { purpurascens } \\
\text { Ch.+ }\end{array}$ & $\begin{array}{c}\text { Boopedon } \\
\text { flaviventris } \\
\text { S.+ S.+ } \\
\text { S.+ S.++. }\end{array}$ & $\begin{array}{c}\text { Taeniopoda } \\
\text { auricornis. } \\
\text { W. }\end{array}$ & $\begin{array}{c}\text { Melanoplus } \\
\text { femur-rubrum. } \\
\text { D.G. }\end{array}$ & $\begin{array}{c}\text { Acheta } \\
\text { Domestica } \\
\text { L. }\end{array}$ & $\begin{array}{c}\text { Brachytrupes } \\
\text { sp. }\end{array}$ & $\begin{array}{c}\text { Periplaneta } \\
\text { australasiae } \\
\text { F.F. }\end{array}$ & $\begin{array}{c}\text { Periplaneta } \\
\text { americana } \\
\text { L. }\end{array}$ & \multicolumn{2}{|c|}{$\begin{array}{l}\text { WHO/FAO } \\
\text { /UNU } 1985 .\end{array}$} \\
\hline \multicolumn{12}{|l|}{$\begin{array}{c}\text { Essential } \\
\text { aminoacids }\end{array}$} \\
\hline Isoleucine & 5.3 & 4.2 & 4.7 & 4.12 & 2.64 & 4.2 & 2.71 & 2.87 & 3.1 & 2.8 & 1.3 \\
\hline Leucine & 8.7 & 8.9 & 8.8 & 4.25 & 5.82 & 7.3 & 6.14 & 5.68 & 5.6 & 6.6 & 1.9 \\
\hline Lysine & 5.7 & 5.7 & 5.5 & 4.15 & 6.17 & 5.6 & 5.98 & 5.60 & 4.0 & 5.8 & 1.6 \\
\hline Methionine & 2.0 & 2.5 & 1.8 & 1.89 & 2.98 & 1.5 & 0.79 & 2.36 & 3.6 & & \\
\hline Cysteine & 1.3 & 1.8 & 2.0 & 1.07 & 1.16 & 2.1 & 1.40 & 0.32 & 2.0 & & \\
\hline $\begin{array}{c}\text { Total } \\
\text { sulphur a.a. }\end{array}$ & 3.3 & 4.3 & 3.8 & 2.96 & 4.14 & 3.6 & 2.31 & 2.68 & 5.6 & 2.7 & 1.7 \\
\hline Phenylalanine & 11.7 & 10.3 & 4.1 & 5.12 & 2.25 & 3.3 & 2.41 & 3.02 & 3.1 & & \\
\hline $\begin{array}{l}\text { Total } \\
\text { aromatic a.a.* }\end{array}$ & 19.0 & 16.6 & 11.5 & 12.8 & 7.89 & 7.4 & 11.7 & 7.57 & 10.0 & 7.4 & 2.4 \\
\hline Threonine & 4.0 & 3.1 & 4.4 & 2.06 & 3.70 & 3.5 & 3.86 & 3.32 & 3.6 & 3.4 & 0.9 \\
\hline Tryptophan & 0.6 & 0.7 & 0.6 & 0.58 & 0.64 & 0.6 & 0.55 & 0.60 & 0.6 & 1.1 & 0.5 \\
\hline Valine & 5.1 & 5.7 & 5.7 & 4.90 & 4.09 & 6.0 & 4.04 & 4.26 & 6.5 & 3.5 & 1.3 \\
\hline Histidine & 1.9 & 2.2 & 2.4 & 1.48 & 2.31 & 2.1 & 2.08 & 1.87 & 2.0 & 1.9 & 1.6 \\
\hline $\begin{array}{c}\text { Total } \\
\text { essential a.a. } \\
\text { No } \\
\text { essential a.a. }\end{array}$ & 53.6 & 51.3 & 47.4 & 37.3 & 37.4 & 40.3 & 39.4 & 35.4 & 40.9 & 35.2 & 13.2 \\
\hline Aspartic acid & 9.3 & 8.7 & 8.8 & 5.57 & 4.24 & 9.0 & 4.77 & 4.37 & 8.8 & & \\
\hline Serine & 5.1 & 4.8 & 4.3 & 3.29 & 2.94 & 4.9 & 3.85 & 3.88 & 4.5 & & \\
\hline Glutamic acid & 5.3 & 10.7 & 15.4 & 6.83 & 6.26 & 8.0 & 7.31 & 6.93 & 13.0 & & \\
\hline Alanine & 7.6 & 6.4 & 5.9 & 5.95 & n.d. & 7.0 & 6.20 & 5.22 & 6.1 & & \\
\hline Arginine & 6.6 & 6.0 & 4.3 & 3.59 & 3.21 & 6.3 & 3.11 & 3.20 & 5.1 & & \\
\hline $\begin{array}{c}\text { Protein } \\
\text { quality score }\end{array}$ & 55.0 & 64.0 & 55.0 & 64.4 & 88.18 & 55.0 & 50.0 & 86.0 & 68.90 & & \\
\hline
\end{tabular}

"Methionine + cysteine, ${ }^{* *}$ Phenylalanine + tyrosine, a.a. = amino acids; + = Oaxaca [27]. L. = Larvae, A. = Adults; P. = Preschooler, A. = Adults n.d. = not determined, Protein quality score is given according to the values standard of WHO/FAO/UNU 1985.

Table 7. Total content of essential amino acids of some edible Orthoptera of Mexico compared with conventional foods (g/100g of protein).

\begin{tabular}{cc}
\hline Order & Values \\
\hline Orthoptera & 35.4 to 53.6 \\
Conventional foods & Values \\
Vegetables & \\
Beans & 6.30 \\
Lentils & 13.2 \\
Soybean & 22.4 \\
Animals & \\
Fish & 40.1 \\
Chicken & 42.7 \\
Beef & 46.8 \\
Egg & 51.5 \\
\hline
\end{tabular}

in their highest value, with the exception of beans. Calcium content in Orthoptera is higher than many products except wheat, maize and beans. In zinc content insects had more than any conventional foods analyzed. With respect to the allowed iron, the vegetables: wheat, barley, oats, soybean and beans provide more quantity than the Orthopteran species. In magnesium the insects species presented the highest values than any conventional foods with the exception of the wheat in the lowest value of orthopterans (Table 11).

\section{Conclusion}

We can conclude that Orthoptera species have a high nutritive value specially those belonging to the family Acrididae that generally allows higher content of the different parameters studied; and also, were the most utilized by people, improving significatively the peasants diet, 
Table 8. Content of vitamins A, C, D, B1, B2 and B6 in some edible Orthoptera of Mexico.

\begin{tabular}{|c|c|c|c|c|c|c|}
\hline Species \& Stage of Development & $\begin{array}{l}\text { A Retinol } \\
\text { (equivs) }\end{array}$ & $\begin{array}{c}\text { C Ascorbic Ac. } \\
\text { (mg/l00g.) }\end{array}$ & $\begin{array}{c}\text { D Calciferol } \\
(\mu \mathrm{g} / 100 \mathrm{~g})\end{array}$ & $\begin{array}{l}\text { B1 Thiamine } \\
\text { (mg/l00g.) }\end{array}$ & $\begin{array}{l}\text { B2 Ribof1avin } \\
\text { (mg/l00g.) }\end{array}$ & $\begin{array}{l}\text { B6 Niacine } \\
\text { (mg/lo0g.) }\end{array}$ \\
\hline Sphenarium borrei B. (A.) & & & 4.12 & 0.50 & 0.66 & 5.04 \\
\hline Sph. purpurascens Ch. (A.) & & & & 0.27 & 0.59 & 1.56 \\
\hline Sph. magnum M. (A.) & & & & 0.83 & 1.28 & 3.97 \\
\hline Acheta domestica L. (L.) & 0.07 & 25.5 & 21.3 & & & \\
\hline A. domestica L. (A.) & 0.03 & 23.9 & & & & \\
\hline Periplaneta americana L. (A.) & 2.90 & 23.8 & 9.67 & & & \\
\hline P. americana L. (L.) & 16.0 & 23.8 & & & & \\
\hline
\end{tabular}

A. = Adult, L. = Larvae Equivs = equivalents.

Table 9. Range of vitamins content of some edible Orthoptera of Mexico compared with conventional foods.

\begin{tabular}{|c|c|c|c|}
\hline Vitamin/Order & Quantity & Conventional Foods $^{*}$ & Quantity* $^{*}$ \\
\hline \multicolumn{4}{|l|}{ Thiamine } \\
\hline \multirow[t]{6}{*}{ Orthoptera } & 0.27 to $0.87 \mathrm{mg} / 100 \mathrm{~g}$ & Rice & 0.44 \\
\hline & & Wheat of Germ & 0.47 \\
\hline & & Lean ham & 0.58 \\
\hline & & Pork & 0.75 \\
\hline & & Sunflower seed & 0.82 \\
\hline & & Yeast & 1.25 \\
\hline \multicolumn{4}{|l|}{ Riboflavine } \\
\hline \multirow[t]{7}{*}{ Orthoptera } & 0.59 to $1.28 \mathrm{mg} / 100 \mathrm{~g}$ & Trout or chicken & 0.19 \\
\hline & & Hamburger & 0.22 \\
\hline & & Pork & 0.24 \\
\hline & & Egg & 0.26 \\
\hline & & Yeast & 0.34 \\
\hline & & Milk & 0.05 \\
\hline & & Liver & 3.52 \\
\hline \multicolumn{4}{|l|}{ Niacine } \\
\hline \multirow[t]{4}{*}{ Orthoptera } & 1.56 to $3.97 \mathrm{mg} / 100 \mathrm{~g}$ & Egg & 0.70 \\
\hline & & Milk & 2.50 \\
\hline & & Maize & 5.00 \\
\hline & & Meat & 24.7 \\
\hline \multicolumn{4}{|l|}{ Vitamin $C$} \\
\hline \multirow[t]{6}{*}{ Orthoptera } & 23.8 to $25 . .5 \mathrm{mg} / 100 \mathrm{~g}$ & Watermelon & 22.0 \\
\hline & & Papaya fruit & 46.0 \\
\hline & & Broccoli & 56.4 \\
\hline & & Tomato juice & 57.0 \\
\hline & & Strawberry & 60.0 \\
\hline & & Orange & 62.0 \\
\hline \multicolumn{4}{|l|}{ Vitamin A } \\
\hline \multirow[t]{6}{*}{ Orthoptera } & 0.03 - 16.0 retinol equivalents & Egg & 97.0 \\
\hline & & Milk & 140.0 \\
\hline & & Gourd & 857.0 \\
\hline & & Spinach & 875.0 \\
\hline & & Carrot & 2025.0 \\
\hline & & Liver & 9011.0 \\
\hline \multicolumn{4}{|l|}{ Vitamin D } \\
\hline Orthoptera & $4.12-21.3 \mu \mathrm{g} / 100 \mathrm{gs}$ & & \\
\hline
\end{tabular}

${ }^{*}[48]$. 
Table 10. Content of several minerals in some edible Orthoptera from Mexico + (g/100g).

\begin{tabular}{|c|c|c|c|c|c|c|c|}
\hline Species & Total ashes & $\mathrm{Na}$ & K & $\mathrm{Ca}$ & $\mathrm{Zn}$ & $\mathrm{Fe}$ & $\mathrm{Mg}$ \\
\hline $\begin{array}{l}\text { S. spp., A. fallax S., B. af flaviventris S., M. } \\
\text { mexicanus S., E. herbaceus B. (L.A.) }\end{array}$ & 2.40 & 0.109 & 0.044 & 0.051 & 0.060 & 0.028 & 0.728 \\
\hline S. histrio G. (L.A.) & 4.79 & 0.426 & 0.422 & 0.096 & 0.021 & 0.023 & 0.744 \\
\hline $\begin{array}{l}\text { S. histrio G. (A.), S. purpurascens Ch. } \\
\text { (L. A.), M. femurrubrum D. G. (L.A.)* }\end{array}$ & 8.33 & 7.05 & 0.250 & 0.115 & 0.017 & 0.016 & 0.354 \\
\hline S. magnum M. (A.) & 1.68 & 0.102 & 0.574 & 0.088 & 0.032 & 0.020 & 0.352 \\
\hline S. histrio G. (A.) & 2.34 & 1.142 & 0.177 & 0.082 & 0.078 & 0.016 & 0.420 \\
\hline S. purpurascens Ch. (A.) & 2.14 & 0.609 & 0.377 & 0.112 & 0.042 & 0.018 & 0.424 \\
\hline S. spp. (L.A.) & 5.56 & 0.915 & 0.068 & 0.120 & 0.032 & 0.044 & 0.824 \\
\hline A. fallax S. (L.A.) & 2.41 & 0.092 & 0.062 & 0.075 & 0.016 & 0.022 & 0.657 \\
\hline $\begin{array}{l}\text { B. af. flaviventris S., S. borrei B., } \\
\text { M. mexicanus S. (L.A.)* }\end{array}$ & 2.49 & 0.066 & 0.062 & 0.112 & 0.024 & 0.038 & 0.943 \\
\hline B. sp. af. flaviventris S. (L.A.) & 2.41 & 0.173 & 0.066 & 0.088 & 0.032 & 0.024 & 0.521 \\
\hline M.mexicanus S. (L.A.) & 2.14 & 0.110 & 0.062 & 0.120 & 0.017 & 0.032 & 0.740 \\
\hline E. herbaceus B. (L.A.) & 2.41 & 0.150 & 0.065 & 0.064 & 0.016 & 0.017 & 0.498 \\
\hline Os (Abracris) flavolineata D.G. (L.A.) & 1.83 & 0.173 & 0.065 & 0.080 & 0.024 & 0.019 & 0.672 \\
\hline Oc. cer. Salinus B. (L.A.) & 0.91 & 0.066 & 0.062 & 0.064 & 0.026 & 0.027 & 0.532 \\
\hline
\end{tabular}

*analyzed species were a1ready fixed and bought at market. L. = Larvae, A. = Adult. S. = Sphenarium; A. = Arphia, B. = Boopedon, $M .=$ Melanoplus, E. = Encoptolophus, Os = Osmilia, Oc. = Ochrottetix.

Table 11. Mineral content of edible Orthoptera of Mexico compared with conventional foods* (g/100g).

\begin{tabular}{|c|c|c|c|c|c|c|c|}
\hline & Total minerals & $\mathrm{Na}$ & K & $\mathrm{Ca}$ & $\mathrm{Zn}$ & $\mathrm{Fe}$ & $\mathrm{Mg}$ \\
\hline Orthoptera & $0.34-5.05$ & $0.07-7.05$ & $0.04-0.57$ & $0.05-0.12$ & $0.01-0.08$ & $0.01-0.04$ & $0.35-0.94$ \\
\hline \multicolumn{8}{|l|}{ Vegetables } \\
\hline Wheat & & 0.57 & 0.27 & 0.15 & 0.00 & 0.05 & 0.36 \\
\hline Barley & & 0.00 & 0.16 & 0.02 & 0.00 & 0.05 & 0.16 \\
\hline Oat & & & & 0.10 & & 0.38 & 0.14 \\
\hline Maize & & & & 0.62 & 0.00 & 0.023 & 0.12 \\
\hline Soybean & & 0.00 & 0.16 & & 0.00 & 0.08 & 0.28 \\
\hline Beans & & 0.02 & 1.52 & 0.16 & 0.00 & 0.08 & 0.18 \\
\hline Carrot & & 0.05 & 0.34 & & 0.00 & & 0.02 \\
\hline Banana & & 0.00 & 0.37 & & & 0.00 & 0.03 \\
\hline \multicolumn{8}{|l|}{ Animals } \\
\hline Beef & & 0.06 & 0.37 & 0.01 & 0.00 & 0.03 & 0.02 \\
\hline Chicken & & 0.09 & 0.32 & 0.02 & & 0.01 & 0.02 \\
\hline Fish & & 0.10 & 0.25 & 0.01 & 0.00 & 0.03 & 0.02 \\
\hline Milk & & & & 0.12 & 0.00 & 0.00 & 0.01 \\
\hline Egg & & & & 0.05 & 0.00 & 0.00 & 0.01 \\
\hline
\end{tabular}

*Modified from [49].

because as it was shown, they generally provide more quantity of the studied nutriments.

Consumption parameters vary depending on the species, ecosystems, season, abundance, weather, habitat and ethnos. Involved Orthopterans are gathered in the field and eaten daily as larvae or adults during the period of their presence or ingested the stored samples already dried in an oven earth, cooking them done or mixed with other meals roasted, fried, simply dried, or incorporated into a special dish. Most of species of the family Acrididae are 
stored and/or commercialized in different localities of the studied states of Mexico and even in the capital of the country.

In Oaxaca, Puebla, Tlaxcala and Hidalgo States grasshoppers are sold in the local markets and represent an important source of money for collectors, middlemen, salesmen and restaurants, there is one Mexican enterprise than can them already fixe. They are also sold canned in other countries (France, USA, and Japan) [11,50,51]. Van der Waal [12] affirms that in South Africa the sale of grasshoppers is a millionaire business. Because of their biologic, nutritional, economical and for the great demand they have, and because also generally they are easy to cultivate, it is important to do additional research about these edible insects, as well as new methods of a gathering efficiently, production, food technology processing and marketing.

\section{REFERENCES}

[1] E. Bergier, "Peuples Entomaphages et Insectes Comestibles,” Imprimerie Rulliére Fréres, Avignon, 1941.

[2] F. S. Bodenheimer, "Insects as Human Food,” W. Junk Publishers, Hague, 1951.

[3] J. Ramos-Elorduy and M. Conconi, "Edible Insects in the World (Liste des Speces. Lieux de Consommation et Ethnies qui les Consomment)," Fourth International Congress of Ethnobiology, Lucknow, 1994, p. 311.

[4] P. Menzeland F. D’Aluisio, "Man eating Bugs," Ten Speed Press, Berkely, 1998.

[5] E. M. Costa Neto and J. Ramos-Elorduy, "Los Insectos Comestibles de Brasil: Etnicidad, Diversidad e Importancia en la Alimentación,” Boletín de la Sociedad Entomológica Aragonesa, Vol. 38, 2006, pp. 423-442.

[6] J. Ramos-Elorduy, "El Consumo de Insectos Como un Hábito Ancestral,” In: Ma. De J. Rodríguez-Shadow and B. Barba de Piña Chán, Eds., Chalchihuite (Homenaje a Doris Heyden), INAH, México, 1999, pp. 275-305.

[7] F. B. de Sahagún, "Historia General de las Cosas de la Nueva España,” Porrúa, México, 1975.

[8] F. B. de Sahagún, “Códice Florentino,” Archivo General de la Nación, México, 1980.

[9] J. Ramos-Elorduy, "Insects: A Sustainable Source of Food?” Ecology of Food and Nutrition, Vol. 36, 1997, pp. 247-276.

[10] J. Ramos-Elorduy, "Insects: A hopeful food source”. In: G. M. Paoletti, Ed., Ecological Implications of Minilivestock (Potential of Insects, Rodents Frogs and Snails), Science Publishers, Inc., Plymouth, 2005, pp. 262-292.

[11] J. Ramos-Elorduy, "Creepy Crawly Cusine: The Gourmet Guide to Edible Insects,” Park Street Press, Rochester, 1998.

[12] B. C. W. Van der Waal, "The Importantce of Grasshoppers (Fam. Acrididae) as Traditional Food in Villages in Northern Transvaal, South Africa," 4th International Con- gress of Ethnobiology Abstracts, Lucknow, 1994, p. 140.

[13] J. Ramos-Elorduy, J. M. Pino M. and M. Conconi, “Ausencia de una Reglamentación y Normalización de la Explotación y Comercialización de Insectos Comestibles en México,” Folia Entomológica Mexicana, Vol. 45, No. 3, 2006, pp. 291-318.

[14] J. C. Heymans and A. Evrard, “Contribution a L'etude de la Composition Alimentaire des Insectes Comestibles de la Province du Katanga (R.D.C.)” Problemes Sociaux du Congo, Vol. 90-91, 1970, pp. 333-340.

[15] G. R. DeFoliart, "Insects as Source of Proteins,” Bulletin of the Entomological Society of America, Vol. 21, No. 3, 1975, pp. 161-163.

[16] R. J. Phelps, J. K. Struthers and J. L. Moyo, "Investigations into the Nutritive Value of Macrotermes falciger (Isoptera-Termitidae)”. Zoologica Africana, Vol. 10, No. 2, 1975, pp. 123-132.

[17] F. Malaisse and G. Parent, "Les Chenilles Comestibles du Shaba Meridional (Zaire),” Naturalistes Belges, Vol. 63, No. 1, 1980, pp. 2-24.

[18] F. Malaisse, G. Parent. "Disponibilité des Produits Sauvages Comestibles de la Region Zambezienne: Ecologie et Valeur Alimentaire des Insectes et des Reptiles,” Abstracts International Symposium, Paris, 1991, p. 20.

[19] S. V. Landry, G. R. DeFoliart and M. L. Sundae, "Larval Protein Quality of Six Species of Lepidoptera (Saturniidae, Sphingidae, Noctuidae)," Journal of Economic Entomology, Vol. 79, No. 3, 1986, pp. 600-604.

[20] K. K. Kodonki, M. Leclercq, M. Bourgeay-Causse, A. Pascaud and F. Gaudin-Harding, "Intérêt Nutritionnel de chenilles d'Attacidés du Zaire: Composition et Valeur Nutritionnelle," Cahiers de Nutrition et de Diététique, Vol. 22, No. 6, 1987, pp. 473-477.

[21] F. Malaisse, “Se Nourrir en Forêt Tropicale,” Les Presses Agronomiques, Glemboux, 1997.

[22] J. Ramos-Elorduy, "Los Insectos Como una Fuente de Proteínas en el Futuro,” 2nd Editon, Limusa, México, 1982.

[23] J. Ramos-Elorduy, "Rôle des Insectes Dans en Forêt Tropicale,” In: C. M. Hladik, A. Hladik, H. Pagezy, O. F. Linares, G. J. A. Koppert and A. Froment, Eds., Alimentation en Forêt Tropicale: Interactions Bioculturelles et Perspectives de Développement, UNESCO, Paris, 1993, pp. 371-382.

[24] J. Ramos-Elorduy, "Insect Consumption as a Mean of National Identity,” In: S. J. Jain, Ethnobiology in Human Welfare, Deep Publication, New Delhi, 1996, pp. 9-12.

[25] J. Ramos-Elorduy, "La Etnoentomología en la Alimentación, la Medicina y el Reciclaje,” In: J. E. LlorenteBousquets., J. J. Morrone, O. Yañez and I. F.Vargas, Eds, Biodiversidad, Taxonomía y Biogeografía de Artró- podos de México: Hacia una Síntesis de su Conocimiento UNAM, Facultad de Ciencias, México, 2004, pp. 329413.

[26] J. Ramos-Elorduy, J. M. Pino, C. M. Márquez, V. F. Rincón, P. M. Alvarado and E. P. Escamilla, "Protein Content of Some Edible Insects in Mexico," Journal of Etnobiology, Vol. 4, No. 1, 1984, pp. 61-72. 
[27] J. Ramos-Elorduy, J. M. Pino, E. P. Escamilla, M. A. Pérez, J. O. Lagunez, and O. de G. Ladrón, "Nutritional Value of Edible Insects from the State of Oaxaca, México,” Journal of Food Composition and Analysis, Vol. 10, No. 2, 1997, pp. 142-157. doi:10.1006/jfca.1997.0530

[28] J. Ramos-Elorduy, R. H. Bourges and J. M. M. Pino, "Valor Nutritivo y Calidad de la Proteína de Algunos Insectos Comestibles de México,” Folia Entomológica Mexicana, Vol. 53, 1982, pp. 111-118.

[29] M. D. Finke, G. R. DeFoliart and M. L. Sundae, “An Evaluation of the Protein Quality of Mormon Cricket (Anabrux simplex H.) When Used as a High Protein Feedstuff for Poultry,” Poultry Science, Vol. 64, 1985, pp. 708-712.

[30] B. J. Nakagaki and G. R. DeFoliart, "Protein Quality of the House Cricket Acheta domestica When Fed to Broiler Chicks,” Poultry Science, Vol. 66, 1987, pp. 1367-1371.

[31] G. R. DeFoliart, "The Human Use of Insects as Food and as Animal Feed," Bulletin of the Entomological Society of America, Vol. 35, 1989, pp. 22-35.

[32] M. Conconi, "Estudio Comparativo de 42 Especies de Insectos Comestibles con Alimentos Convencionales en sus Valores Nutritivo, Calórico, Proteínico y de Aminoácidos, Haciendo Énfasis en la Aportación de Aminoácidos Esenciales y su Papel en el Metabolismo Humano,” Prof. Thesis, Portal de la Universidad Nacional Autónoma de México, 1993.

[33] O. de G. Ladrón, P. Padilla, L. García, J. M. M. Pino and J. Ramos-Elorduy, "Amino Acid Determination in Some Edible Mexican Insects,” Amino Acids, Vol. 9, No. 2, 1995, pp. 161-173.

[34] J. Ramos-Elorduy, J. M. M. Pino and M. O. González, "Digestibilidad in Vitro de Algunos Insectos Comestibles de México,” Folia Entomológica Mexicana, Vol. 49, 1981, pp. 141-154.

[35] J. J. Dreyer and A. S. Weameyer, "On the Nutritive Value of Mopanie Worms," South African Journal of Science, Vol. 78, 1982, pp. 33-35.

[36] R. H. Bourges, J. Ramos-Elorduy, J. M. M. Pino and M. N. Suárez, "Bioensayos en Rata Wistar Para Estimar la Calidad Proteínica de Tres Insectos Comestibles de México,” Resúmenes XVI Congreso Nacional de Ciencia y Tecnología de Alimentos, Vol. 20, No. 4, 1985, pp. 23-34.

[37] J. Ramos-Elorduy and J. M. M. Pino, "Digestibilidad proteinica in Vitro de Tres Avispas Comestibles de México," xvi Congreso Tecnología de Alimentos, Vol. 20, No. 4,
1985, pp. 24.

[38] J. Ramos-Elorduy, Los Insectos Como una Fuente de Proteínas en el Futuro, WHO, Geneva, 1974.

[39] J. Ramos-Elorduy and J. M. M. Pino, "Contenido Calórico de Algunos Insectos Comestibles de México,” Revista de la Sociedad Química de Mexico, Vol. 34, No. 2, 1990, pp. 56-68.

[40] J. Ramos-Elorduy, "Energy Supplied by Edible Insects from Mexico and Their Nutritional and Ecological Importance,” Ecology of Food and Nutrition, Vol. 48, No. 3, 2008, pp. 280-297. doi:10.1080/03670240701805074

[41] J. Ramos-Elorduy, J. M. Pino and V. H. C. Martínez, "Base de datos de insectos Comestibles de México," Unibio (Unidad de Biodiversidad del IBUNAM), México, 2011, in Press.

[42] D. Otte, "Grasshoppers (Acridomorpha). Orthoptera Species File No. 4," The Orthopterists' Society and the Aca- demy of Natural Sciences of Philadelphia, Philadelphia, Pennsylvania, 1995.

[43] D. Otte, “Orthoptera Species File 5: Grasshoppers (Acridomorpha); D. Acridoidea (Part)”. The Orthopterists' Society and the Academy of Natural Sciences of Philadelphia, Philadelphia, 1995.

[44] D. Pearson, "The Chemical Analysis of Food," 6th Edition, J.\&A. London, 1970.

[45] AOAC, "Official Methods of Analysis," AOAC International, Washington DC, 1975.

[46] J. Ramos-Elorduy, E. Motte Florac and M. Conconi, "Entomophagie au Mexique,” Peters Louvain, Paris, 2006.

[47] WHO/FAO/UNU, "Report: Energy and Protein Requirements,” WHO Technical Report Series No. 724, Geneva, 1985.

[48] R. D. Mahan and T. Arlin, "Nutrición y Dietoterapia," McGraw-Hill, Boston, 1995.

[49] J. Ramos-Elorduy, J. L. Muñoz and J. M. Pino M., “Determinación de Minerales en Algunos Insectos Comestibles de México," Revista de la Sociedad Química de México, Vol. 42, No.1, 1998, pp. 18-33.

[50] R. Taylor, "Butterflies in My Stomach (or Insects in the Human Nutrition)," Woodbridge Press, Santa Barbara, 1975.

[51] J. Mitsuhashi, "Insects as a Traditional Food in Japan," Ecology of Food and Nutrition, Vol. 36, No. 2-4, 1997, pp. 187-199. doi:10.1080/03670244.1997.9991514 


\section{Proposed Referees}

\section{Eraldo Medeiros Costa Neto}

Departamento de Ciências Biológicas

Universidade Estadual de Feira de Santana

Km 03, BR 116 Feira de Santana, Bahia Brasil CEP 44031-460

e-mail: eraldont@hotmail.com

\section{Arnold van Huis}

Personal Chair, Professor Tropical Entomology

PhD 1981, Wageningen University

Tel: 31-(0)317-484653

E-mail: arnold.vanhuis@wur.nl

\section{Florence V. Dunkel.}

Associate Professor, Ph.D from Univ. of Wisconsin Office: Room 3 Marsh Lab

Lab: Room 6 Marsh Lab

Office - (406) 994-5065

Fax - (406) 994-7600

E-mail: ueyfd@montana.edu

\section{Andrea Pieroni}

University of Gastronomic Sciences

Via Amedeo di Savoia 8

I-12060 Pollenzo/Bra (Cn)

Italy

E-mail: a.pieroni@netcologne.de 